\title{
The mission of ethics teaching for the future
}

\author{
Diego Gracia ${ }^{1}$
}

Published online: 6 January 2016

(C) Springer International Publishing AG 2015

\begin{abstract}
The goal of education is the promotion of the intellectual, moral and human skills as well as the character of human beings. In Kantian terms, it is to foster their autonomy. This is a quite strange activity, given most of the influences the environment exerts on human beings (through the media, as well as through commercial, political, and cultural propaganda) are pursuing the exact opposite: compel us to do what they want us to, that is, to act heteronomously. Ethics is quite the only academic discipline whose direct aim is to empower people to do what they should; hence its enormous importance, comparable to its complexity. But all throughout Western history, ethics has also fallen into the habit of promoting heteronomy over autonomy. Such practice claims for immediate correction in such a troubled moment as the initial steps of the 21 st century.
\end{abstract}

Keywords Ethics $\cdot$ Bioethics $\cdot$ Deliberation $\cdot$ Teaching ethics $\cdot$ History of ethics

Ethics education has always been a complex and difficult issue. When teaching disciplines composed primarily by objective facts, such as electronics, geometry or medicine itself, all that needs to be conveyed during the teaching process is knowledge, or knowledge and skills, and the problem of teaching is limited to establishing the most appropriate procedures to achieve such objectives: schedules, timetables, teaching methods to be used, how to assess students, etc. The problem with ethics is that it is not directly linked to knowledge and skills, but to the attitudes and the character of the people. As it is well known, that is what the Greek word éthos means, habit or character of a human being, just as mos in Latin. The first question then is whether this dimension of human personality can be taught. And, even if the answer is affirmative, if it should be taught, given that doing so might prove to be a serious intrusion into the lives of other human beings.

Diego Gracia

dgracia@fcs.es

1 School of Medicine, Complutense University of Madrid, 28040 Madrid, Spain 
In the specific case of bioethics, this concern is not new. In fact, 30 years ago, on 1985, a large number of teachers of medical ethics in different American medical schools published an article in the New England Journal of Medicine. In this article they presented a true Solomonic measure as potential solution to the problem: given young people that join medical schools have already formed the core of their characters, the direct educational objective of teaching medical ethics should not be the change or improvement of their attitudes and character. This should remain as an indirect objective, achieved through the improvement of their knowledge and skills. "A medical-ethics curriculum is designed not to improve the moral character of future physicians but to improve those of sound moral character with the intellectual tools and interactional skills to give that moral character its best behavioral expression". (Culver et al. 1985). This seems paradoxical, given the fact that when looking at the etymology of the word ethics, it is implied that it can be taught directly as such.

This topic is as old as Western culture itself. In fact, it was already raised starkly by Socrates, the undisputed and unquestionable father of ethics as a philosophical discipline as well as of its teaching. Socrates' dilema is precisely this: whether ethics can be taught or not. His answer was positive, but only after avoiding certain biases that would generate wrong attitudes, incompatible with any true attempt to teach ethics.

\section{The two classical models of moral teaching}

This unveils the need to analyze books currently approved for the education of ethics in secondary education and high school. They consistently fall into one of the two basic errors that has sterilized ethics training throughout the centuries. The first one is the approach that may be called "doctrinaire" or "imperative" and the other, more modern, and to no extent less harmful, the one purely "neutral" or "informative".

The first is the one has taken the lion's share of errors in the teaching of ethics in Western culture, since its very beginning in ancient Greek and Roman times. Doctrina is an abstract Latin noun derived from the verb doceo, to teach, so that doctrina means the content that is taught, reason why the model can be called "doctrinaire". The goal of the teaching process has been for the most part of our history "indoctrination", a way of "indoctrinating" people. Doceo, on the other hand, translates the Greek dokéo, to believe, to think, from which derives the noun dóxa, opinion, belief. Those opinions configure the so-called tópoi or loci communes, the commonplaces teachers should give or transmit to their disciples (the Latin word traditio derived from the verb trado, means to give, to transmit or to deliver). The mission of the teacher is therefore none other than to deliver this content of the doctrine to the following generation, who play the role of "discent" or learner element (disco, to learn). The goal of the learning process is not to reason or to discuss, but only to safeguard the "tradition" that is considered sacred and shall be kept reverently protected from any modification or criticism. The place where tradition was collected in order to be used in the teaching process, is called documentum. Parallel to the verb doceo, to teach, is disco, to learn, so that doctrina takes in the disciple the character of disciplina. He/she who teaches and transmits the deposit is called doctus, and the recipient, discipulus. The person who is submissive and assumes obediently the doctrine is docilis, and otherwise, when she does not like to be cultured (from colo, to cultivate or to culture) it is called $d y s$-colus 
and in-cultus. The only one virtue expected in the student is docility. This has been the paradigm of ethics' teaching for most human history.

In modern times this way of training new generations came into crisis. This was because of the coexistence in Europe of diverse cultures and traditions with different value systems, especially after the religious wars of the 16th and 17th Centuries. The traditional value monism was substituted by a society in which a plurality of different and in some cases opposite values coexisted. And the problem was how to teach ethics in such circumstances, particularly when the teaching is done in public centers. The slogan that won was "neutrality". Public institutions had to be neutral, not favoring any one of the alternative value options present in their midst. And given pure neutrality is impossible, what prevailed was the merely "informative" attitude, so that the teacher's role was restricted to illustrate and inform the main data available about the topic at stake, avoiding any value judgment, given that when doing so he would be violating the human right to freedom of conscience of the student. This is the background of the "informative" or "expert" model of teaching, in which the teacher talk about everything but without making any value judgments, except when there is a universal consensus on them, and no room for plurality or pluralism.

A little less than a century ago, on 1919, Max Weber argued before the students of the University of Munich that "one can only demand of the teacher that he have the intellectual integrity to see that it is one thing to state facts, to determine mathematical or logical relations or the internal structure of cultural values, while it is another thing to answer questions of the value of culture and its individual contents and the question of how one should act in the cultural community and in political associations. These are quite heterogeneous problems. If he asks further why he should not deal with both types of problems in the lecture-room, the answer is: because the prophet and the demagogue do not belong on the academic platform" (Weber 1946, 146).

A modification of this model was the one introduced Freud in his psychoanalytic technique. Freud established "neutrality" as a supreme principle of the analytic therapy, in order to prevent the improper influence of the therapist on the patient's values. The only thing allowed was to help patients "clarify" themselves. This method was applied to teaching in general, and to the teaching of ethics in particular in the mid-twentieth century, being known by the name of "values clarification". Louis Raths built it upon the theoretical approach to values of John Dewey, focusing on the "process of valuing", as Dewey suggested (Rath et al. 1966). In this way, Raths and his disciples think it is possible to overcome the two traditional methods in training values. They call the first one "inculcation", because it tries "to pass on our most cherished values and beliefs to those whose lives we touch." (Simon et al. 1972, 6) It has been and remains the most common. They call the other approach "modeling", because the teacher will present $\mathrm{him} /$ herself in it "as an attractive model who lives by a certain set of values." (Simon et al. 1972, 7) According to the authors, this approach has also many limitations, since young people are exposed to many and very different models, and therefore find it extremely difficult to identify which model they should emulate or follow.

Given that, the authors propose the values clarification model as an alternative, defined as "a more conscious and deliberate approach for helping people make their own best decisions." (Simon et al. 1972, 11) The goal of the method "is all about developing and acting upon one's personal values" (Simon et al. 1972, 11). The objective, therefore, is neither to transmit a particular set of values, nor to deliberate 
with students about values, but to help them understand how to become aware of the beliefs and behaviors they consider significant and would like to maintain. The process of values clarification does not intend to discern what values are better than others, but "to achieve a fuller integration of our feelings, beliefs, and behavior." (Simon et al. $1972,10)$ What is at stake is not the critical analysis of the values or beliefs that one already has or that he/she may be acquiring, but to achieve the greater possible consistency between those beliefs one has and his/her behavioral patterns. The question is not discussing on values but seeking coherence between values and practical life.

This method was soon criticized. The most frequent criticism was that it seems too "neutral", "a purely selfish and amoral approach to making life's decisions" (Simon et al. 1972, 11). In fact, the teacher pursues the active teaching of values, while professing non-belligerence in matters of value. He treats value-laden questions trying to stay value-free; an attitude many would perceive as inconsistent and dangerous. As an example of criticism, here is the one by Emy Gutmann: "Liberal neutrality supports the educational method of 'values clarification', which enjoys widespread use in schools throughout the United States. Proponents of values clarification identify two major purposes of moral education within schools. The first is to help students understand and develop their own values. The second is to teach them respect for the values of others. Advocates of values clarification view it as the pedagogical alternative to indoctrination" (Gutmann 1987, 55). What needs to be done in schools is to help people clarify their own values without valuing them. Values cannot be valued, because there is not an objective benchmark from which to do so. Values are relative, and the only one absolute principle is the respect for the values of everyone else. In matters of value, therefore, you must remain "neutral." After explaining the method, Amy Gutmann criticizes it strongly, saying that neutrality is not taking no position in the matter of values, but taking a wrong one: in this sense we would be rewarding wrong values. She writes: "Treating every moral opinion as equally worthy encourages children in the false subjectivism that 'I have my opinion and you have yours and who's to say who's right?' [...] The toleration and mutual respect that values clarification teaches is too indiscriminate [...] If children come to school believing that 'blacks, Jews, Catholics, and/or homosexuals are inferior beings who shouldn't have the same rights as the rest of us', then it is criticism, not just clarification, of children's values that is needed [...] Indiscriminate respect for children's values cannot be defended either as an ultimate end or as a tenable means of cultivating good character" (Gutmann 1987, 56).

Gutmann's criticism was not the only one that was presented during the eighties. Many others emerged from the most conservative sectors of the American society, during that decade of political and cultural boom. During the nineties, new alternative proposals emerged, trying to go further, while at the same time assuming many things from the values clarification experience, as well as considering the main arguments of its critics. One of these new proposals is that known as "Comprehensive Values Education" (Harmin 1988; Kirschenbaum 1992).

The creators of the values clarification approach provided with an answer to those who criticized their method as excessively neutral, stressing that it is a good way of promoting freedom, justice, rationality, equality, and other democratic and civic values between young people, and that only in very specific issues, including those related to politics, religion, health, personal preferences and the like, values clarification is value 
free. This defense is certainly correct. There is no doubt that the method of values clarification is a way of dealing with values. There are no value-free activities, even when intended. But the question is if neutrality is the best way to educate in values. It seems very strange that what the proponents mean by value never appears clearly described in their main books. When this concept is not precisely defined, it seems difficult to teach to young people what values are, what types are there and what characteristics, how to identify them, what is a conflict of values, how to analyze and try to solve them, etc.

\section{Back to Socrates}

This is our current standpoint. If we were to revise the current ethics programs in secondary education and high school, we would often find one of both described styles. As an alternative, we propose a third one, which can be called "Socratic" or "deliberative".

While reading the first period of Plato's dialogues, one of the first surprising things you come across is that Socrates never tried to impose his own views or own opinions to the rest. In fact, he almost never gives an opinion. Hence we do not retain any moral maxim defended by him. The only one transmitted to us says that "doing wrong is fouler than suffering it." (Plato 1967, Gorgias 475 c) Socrates didn't try to indoctrinate his partners. It is far from the doctrinaire model. Socrates didn't instruct in any doctrine. He says he doesn't have a doctrine himself. Many of his partners did not believe him, and that is the origin of the accusation of ironist. Saying that all he knows is that he doesn't know, Socrates would be laughing at them. And the top of his irony is that demonstrating them they are wrong in their previous statements, he would not give them the right answer.

Socrates neither indoctrinated, nor instilled a doctrine. But at the same time he rejected neutrality in values. In fact, he was very belligerent in their analysis, devoting significant time and all his intellectual acuity in their identification. That acuity served him not to say what is virtue, or what is piety, but only to know what they are not. And he did so providing reasons. Socrates used reason to look for inconsistencies in the propositions taken for granted as right by his partners. His "elenctic" method was basically negative, and consisted in the refutation of the wrong assumptions of his opponents. Refutation, which has a merely "negative" character, provides with understanding of what it is not, but not of what it is. The goal of the Socratic method was, obviously, to guide people to their positive answers, but these should be discovered by each one of them, taking into account the suggestions of each internal daimon. It cannot be taken for granted that these answers should be the same for everyone in similar circumstances. In any case, and because values are at stake, these answers cannot be completely "rational", but only "reasonable". (Gracia 2010 55-71) If values were like mathematical entities, the procedure to take right decisions would be demonstration (apódeixis), but not refutation (élenkos). On values and practical decisions only "reasonableness" is achievable. This was the Socratic method, at least in the interpretation given by Aristotle. The type of logic affordable in the so-called practical propositions, like these typical in Ethics, Politics, and Medicine, is not the "apodictic" one but only the "dialectical" (Aristotle 1960, Topica I 1: 100 a 18-b 23). 
This means that there is a kind of reasoning other than the apodictic one, which is typical of all kinds of practical knowledge. This was the conclusion achieved by Aristotle from the Socratic teaching. Apodictic reasoning gives truth, and problems have only one right solution, which necessarily make false all other possible answers. In the case of practical reasoning, however, problems can have more than one "reasonable" solution. And the method to find the best one in each case is called "deliberation". (Gracia 2003, 227-233) Socrates was the father of this method, that one of his disciples, Aristotle, systematized, but that only recently began to drive the attention of philosophers. Deliberation is the method, and the target is making reasonable, "prudent" or "wise" decisions. Prudence is the virtue of the judgments and decisions that are reasonable but not completely rational, and therefore probable but not certain. Practical issues may have more than one reasonable and prudent solution. Even in the same situation, two people can take two different reasonable solutions, and even one person can take two diverse solutions in two different times, remaining all other variables the same.

The goal of deliberation is to give reasons on the facts, values and beliefs at stake, but being aware that these reasons cannot be neither completely rational, nor fully explained. Hence deliberation is only possible when people is open to the motivations of all others who will be affected by the decision, listening to them, in order to enrich their own point of view and increase the reasonableness and prudence of the decision. Deliberation is not neutral in matters of value, but at the same time it is not a process of indoctrination. It departs from the assumption that all concrete decisions are plenty of uncertainty, and that the way of diminishing it until a reasonable level is through the exchange of arguments. (Gracia 2010, 55-71) In the case of ethics, this deliberation should be done not only on factual data, but also on values, in order to determine our moral duties in the best possible way. (Gracia 2011, 84-94) The aim of the deliberation process is to enrich the analysis of the question at stake, trying to increase the wisdom of the decisions to be taken. Its goal is not to reach a general consensus, as it is generally thought, but to promote wisdom in the field of practical decisions, even when decisions are diverse and depend on the diversity of people.

Deliberation has its premises. Nobody is born knowing hoy to deliberate, at least when it must be practiced collectively. We have to learn it. This learning should be basic and compulsory in the academic training of each person, even at primary school. In order to be able to deliberate, you need to have certain virtues that are quite rare in our environment: we need to think that others may be right, at least as much as we are; that their views can enrich and enhance me in order to be more wise and prudent; that none of this is possible without the listening ability and the willingness to understand the different or conflicting points of view; that everyone should be able to give an account of their own value choices, despite how difficult this could be; that, in short, one can assume without fear their own fallibility. This was the great Socratic discovery, the wisdom in knowing we do not know. Only after this discovery, the others become essential in order to increase the reasonableness and prudence of our decisions. In deliberation a certain intellectual humility is necessary. Believers that they are in possession of the absolute truth, not only don't need to deliberate, but they would not be able even in the case they would want to. Deliberation is at odds with the narcissism that, unconsciously, we all have and cultivate to a certain extent. Hence learning to deliberate is not just a school of life, but also of mental health. He/she who 
knows how to deliberate is less dependent of his/her unconscious forces, has a better control of his/her anxiety, using less the ego defense mechanisms, and being less vulnerable, precisely because he/she is not seeking invulnerability. Knowing not to know is a great achievement. The problem begins when one does not know he/she doesn't know. Deliberation is the best way to know our own intellectual limits.

Deliberation, thus understood, is a school of life. And, of course, it is essential in bioethics (Gracia 2001, 223-232). Bioethics courses should be true schools of deliberation. The most important goal of an ethics course is not how to solve problems but how to deliberate correctly. Beyond the doctrinal and the purely informative and neutral bioethics, it is necessary to promote a deliberative bioethics. Now the goal of the teacher of ethics is neither to impose, nor even to inform or illustrate; it is to deliberate with students. But this is not an easy task. Not only due to the problems the students could show, but especially because deliberation is extremely demanding on the teacher. At the very least, that he is capable of deliberating well. This requires a very long training. Deliberation requires some knowledge, but also some skills and, above all, some basic and developed attitudes. It is not enough, therefore, to read a book on the subject. One needs to know, and at the same time to practice. The only way of learning how to deliberate is deliberating.

\section{References}

Aristotle. 1960. Topica. Cambridge: Harvard University Press.

Culver, Charles M., K. Danner Clouser, Bernard Gert, Howard Brody, John Fletcher, Albert Jonsen, Loretta Kopelman, Joanne Lynn, Mark Siegler, and Wikler Daniel. 1985. Basic curricular goals in medical ethics. New England Journal of Medicine 312: 253-256.

Gracia, Diego. 2001. Moral deliberation: The role of methodologies in clinical ethics. Medicine, Health Care and Philosophy 4(2): 223-232.

Gracia, Diego. 2003. Ethical case deliberation and decision making. Medicine, Health Care and Philosophy 6: 227-233.

Gracia, Diego. 2010. Philosophy: Ancient and contemporary approaches. In Methods in medical ethics, 2nd ed, ed. Sugarman Jeremy and Daniel P. Sulmasy, 55-71. Washington, DC: Georgetown University Press.

Gracia, Diego. 2011. Deliberation and consensus. In The SAGE handbook of health care ethics, ed. Ruth Chadwick, Henk ten Have, and Eric M. Meslin, 84-94. London: SAGE Publications.

Gutmann, Amy. 1987. Democratic education. Princeton: Princeton University Press.

Harmin, Merrill. 1988. Values clarity, high morality - let's go for both, Educational Leadership May: 24-30.

Kirschenbaum, Howard. 1992. A comprehensive model for values education and moral education. Phi Delta Kappan 73(10): 771-776.

Plato. 1967. Gorgias. In: Plato in twelve volumes, Vol. 3 trans. by W.R.M. Lamb. Cambridge, MA: Harvard University Press; London: William Heinemann Ltd.

Rath, Louis, Merril Hermin, and Sidney Simon. 1966. Values and teaching. Columbus: E. Merrill.

Simon, Sidney B., Leland W. Howe, and Howard Kirschenbaum. 1972. Values clarification: A handbook of practical strategies for teachers and students. New York: Hart Publishing Company.

Weber, Max. 1946. In From Max Weber: Essays in Sociology, ed. H.H. Gerth and C.W. Mills. Oxford: Oxford University Press. 